\title{
Tracing the Local: The Translator-Travellee in French Accounts of India
}

\author{
Sanjukta Banerjee
}

\begin{abstract}
This paper seeks to trace the presence of the "translator-travellee" in the construction and dissemination of French travel writing on India from the eighteenth century. Drawing on the concept of "language as a local practice" (Pennycook 2010), it examines the travellers' descriptions of India's linguistic landscape to underscore the interactional history of representation that the conventions of European travel writing have tended to elide, particularly in the context of the subcontinent. The local in this paper is approached as a process inextricably linked with the social and the historical, and its exploration is aimed at rendering visible the role of the Indian translator/interpreter in embedding vernacular knowledge in international discursive networks at a crucial period in the subcontinent's encounter with the West.
\end{abstract}

Keywords: French travel writing; India; translator-travellee; multilingualism; local

Résumé : Cet article a pour objet de retracer la présence du "traducteur-visité" dans la construction et la diffusion de récits de voyage sur l'Inde par des Français au dix-huitième siècle. En s'appuyant sur la notion de "langue comme pratique locale" (Pennycook 2010), l'auteure examine les descriptions du paysage linguistique de l'Inde afin de souligner l'élision de l'histoire interactionnelle de la représentation en raison des conventions régissant les récits de voyage européens, particulièrement dans le contexte du souscontinent. Le local est considéré ici comme un processus inextricablement lié au social et à l'historique, et son exploration vise à mettre en relief le rôle du traducteur/interprète indien dans l'enchâssement des savoirs vernaculaires dans les réseaux discursifs internationaux à un moment décisif de la rencontre entre l'Inde et l'Occident.

Mots clés : récit de voyage français ; Inde ; traducteur-visité ; multilinguisme ; local

Resumo: Este trabalho procura rastrear a presença do "tradutor-travellee" na construção e disseminação da literatura de viagem francesa sobre a Índia no século XVIII. Com base no conceito de "língua como prática local" (Pennycook 2010), examinam-se as descrições da paisagem linguística da Índia feitas por viajantes a fim de sublinhar os registros interacionais da representação que as convenções da literatura de viagem europeia tenderam a elidir, especialmente no contexto do subcontinente. O local é aqui abordado como um processo indissociável do social, do histórico, os quais exploramos com o objetivo de tornar visível o papel do tradutor/intérprete indiano na incorporação do conhecimento vernáculo em redes discursivas internacionais, em um período crucial do encontro do subcontinente com o Ocidente.

Palavras-chave: literatura de viagem francesa; Índia; tradutor-travellee; multilinguismo; local

Resumen: El presente trabajo busca rastrear la presencia del "traductor-travelee" en la construcción y diseminación de los relatos de viaje franceses acerca de la India en el S. XVIII. Con base en el concepto de la "lengua como una práctica local" (Pennycook 2010), investigamos las descripciones del paisaje lingüístico de la India realizadas por los viajeros; en ellas buscamos resaltar la historia interaccional de representación que las convenciones de la escritura de viaje europea han tendido a omitir, especialmente en lo referente al subcontinente. Abordamos lo local como un proceso indisociable del social y del histórico y lo exploramos con el fin de otorgar visibilidad al papel del traductor/intérprete de la India en la incorporación del conocimiento vernáculo a redes discursivas internacionales en un periodo crucial del encuentro entre el subcontinente y Occidente.

Palabras clave: relatos de viaje franceses; India; traductor-travellee; multilingüismo; local 


\section{Introduction}

In his introduction to the anthology of eighteenth-century French travel writings on India, titled Les Indes Florissantes (1991), editor Guy Deleury claims that the accounts, largely eclipsed by the "Histoire officielle" of the period (intro. viii), expose the latter for what it is: a lie. In one chapter, Deleury seeks to reinforce this jab at the Anglophone discourses of eighteenth-century India that portrayed the region as culturally and politically impoverished (viii), ${ }^{1}$ by introducing the reader to the travellers' accounts of India's languages -an aspect of their experience that he posits as having been integral to the French view of the region's linguistic and cultural plurality. While the 21-page chapter (the shortest of twelve in the 998-page tome), offers the reader only glimpses of the descriptions of India's linguistic landscape, the excerpts included there, replete with anxiety-ridden references to the region's innumerable languages, draw attention to the questions explored in this paper: Through what concept of language practice could we read language relations in eighteenth-century India as described in the accounts? How might the "travellee" (Pratt) figure in that reading?

This paper seeks to address these questions through an examination of three accounts by French travellers-Abraham Hyacinthe Anquetil-Duperron, Pierre Sonnerat and Foucher d'Obsonville-who visited India in the second half of the eighteenth century, a period of major transition in India's contact with the West. Drawing on Alastair Pennycook's concept of "language as a local practice" that adapts, transforms, and rearticulates global histories (79), I focus on the travellers' observations of the relation between India's vernacular languages and Sanskrit. My goal is to shed light on the mutually constitutive roles of the two, and to trace the intervention of the native translator (henceforth referred to as "translator-travellee") in the Indo-French encounter, and in the "traffic of meaning" (Dasgupta, Pennycook) generated by it. To this end, my analysis of the texts is interwoven with observations on the linguistic ideology at work in their construction.

\section{Travel writing, translation, mobility}

Travel writing and translation have been examined and theorized as interconnected and often comparable activities, not the least because travellers have always relied on local interpreters and translators. In conveying the new in terms of the known and familiar, both engage in a kind of renewal through repetition; as mediators and witnesses, both have been central to our knowledge of the unfamiliar and of history. In her analysis of the parallels between the two activities, Susan Bassnett (Comparative Literature) draws an analogy between the traveller/mapmaker and the translator as two crucial players in the construction of knowledge-both plagued by issues of visibility/invisibility. In the context

\footnotetext{
${ }^{1}$ I do not necessarily agree with Deleury's view of Anglophone accounts of India, since these underwent significant change during the late eighteenth and early nineteenth centuries, and therefore merit attention as a body of texts marked by variety.
} 
of this study, it is important to note that European travel writing-its history intimately linked to the history of mapping and surveying territories and the natural world (Bassnett, "Travel Writing and Gender" 231)—often ran parallel, in the eighteenth century, to the process of mapping linguistic landscapes. Crucially, understanding the local in this study rests on recognizing the mobility implicit in all translation activity: Probal Dasgupta, visualising translation as a road, observes, "[w]hen you translate, you are part of the traffic" (57). This view of the nexus between travel and translation recognizes that what is global happens through the local.

\section{The "local" in language practice}

In his elaboration of "language as a local practice", Pennycook has in mind current contexts of language use, but his position, drawing on Massey, Lefebvre, and Soja, that "all views of language are located in certain histories and articulated in certain perspectives" (5), is relevant to my study. As he argues, "the spatial turn is [...] both a reaction to the changing conditions of movement [...] and a rethinking of the ways in which space has been understood" (55, emphasis added). Space, being socially produced, must be considered as interwoven with the social and the historical, encompassing time and change, and therefore as a process. This spatial view-at odds with a view that emphasizes a dichotomy between time and space-rests on an understanding of language activities as producing both time and space as inextricably interlinked phenomena (56). If we view space as socially produced and as "the third existential dimension that needs to be considered alongside the historical and the social" (Soja, Thirdspace 3), what emerges is an understanding of language as a resource rather than an entity in the "traffic of meanings" (Pennycook 67-68), and a language-place relation that is always emergent and approximate.

\section{Language as a countable entity}

In his Recherches historiques et geographiques sur I'Inde (1786), Anquetil-Duperron, foremost among the French Orientalists to have travelled ${ }^{2}$ in India, attempts to enumerate the languages of the country:

Travelling down the peninsula, one comes across the jargon of Balasore, corrupted from Bengali [...] then Telugu - it is the Indian language that is closest to Sanskrit. Its area extends from Ganjam on the Orissa coast to 810 coss $^{3}$ north of Tamil-speaking Pulicat [...] The coast of the Pescherie has a particular jargon, a corrupt Tamil that resurfaces west of Cape Comorin. (p. x-xi) (My translation, emphasis original)

The traveller lists other languages of the land: Tibetan, Persian and Hindustani in the north; Bengali, Tibetan and Hindustani in Bihar and Bengal; pure Tamil, Kannada, Marathi

\footnotetext{
2 Between 1755 and 1762.

${ }^{3} \mathrm{~A}$ measure of length in India, varying in different regions from approximately 1.25 to 2.5 miles (or 2 to 4 kilometres) (OED).
} 
on the west coast; and numerous mixings of these. To communicate with the people of India, he concludes, one must know not only nine languages and their alphabets, but also the local jargons and dialects-a prospect more terrifying than that of crossing the Ghats of India (xii).

The description of the vernaculars of India as "corrupt languages" and "jargons" could serve as a "point of entry into studying the formation and meaning of Western cultural practices themselves" (Said, Culture and Imperialism 191) and help trace the emerging ideology of monolingualism in eighteenth-century Europe-most noticeably in France ${ }^{4}$-rooted in the notion of languages having a single source (see Calvet). Interestingly, at one point in the narrative, Anquetil-Duperron's remark that the reader would be well-advised to look at a general map of India while reading his description (xi) foregrounds the challenge of trying to establish one-to-one relations between languages, regions and communities in the subcontinent. ${ }^{5}$ There is little to suggest that in eighteenthcentury India, in any general sense, languages functioned as indicators of ethnicity, or that people speaking "languages of Place" identified themselves as constituting groups united through language and place (Pollock 510). ${ }^{6}$ However, the traveller's description of occurrences of language mixing in India-overwhelming the nine tongues he seeks to fix to the places he travels through-underscores not so much the absence as the "indeterminability" (Kaviraj 142) of boundaries between languages, regions and communities. Of note here is the use of the enumerative, ${ }^{7}$ amenable to imagining language communities as contained within regional boundaries. Oriental scholarship of India was dependent on the construction of a body of "scientific knowledge", underpinned by an ideology of languages and their speakers being countable, and bolstered by assumptions of an "essentialized language-object situated and physically located in concepts of space founded on a notion of territorialisation" (Makoni and Pennycook 10). The account of overlapping tongues and barely perceptible yet unmistakable differences, however, suggests a linguistic landscape that needs to be understood in terms quite inimical to the spatial mentality that tethers communities to languages, people to places.

The notion of languages as discrete entities has been described by linguists as a European artefact of classificatory procedures such as standardization rather than a reflection of communicative practices (Romaine 12). Seen in this light, French naturalist Pierre Sonnerat's ${ }^{8}$ observations are revealing: "living languages of India have enough rapport with [Sanskrit] to be considered the latter's offspring, but corrupted by mixing with bad jargons" (229). Following a general mapping of the languages of the subcontinent, he focuses on Tamil, the one he is most familiar with, which is, according to him, the most deficient of India's languages (229). Minute changes in sound alter the meanings of entire sentences, leading to incomprehension (242). Such confusion, he adds, pervades Indian

\footnotetext{
${ }^{4}$ For a discussion of this point, see Banerjee.

${ }^{5}$ I do not posit India as a unique case, only as the case under examination in this study.

6 Here I am underlining the general flexibility that marked these relations in India before the arrival of European influence. There may well be regional exceptions to this noticeable in diachronic studies, like the one by Pollock.

7 Said has noted the preponderance of the "anatomical and enumerative" in Orientalist discourses of Asia (Orientalism 72). This is often illustrated in discourses surrounding India's languages.

8 Travelled India between 1774 and 1781.
} 
society in general. The same gods become unrecognizable in the local translations of Indian mythology (242). "The sacred books of Indians are all the same, but [the people] do not always agree on their beliefs. The reason for this inconsistency may be found in those very books, which have been either badly translated or wrongly interpreted in the different idioms." (341)

Sonnerat bemoans the imperfect knowledge the Tamils have of their religionimperfect since it is based on the faith they put in the vernacular translations, which are far removed from the Sanskrit originals. This is because, he speculates, the translators altered the texts of the Puranas and inserted fables well-known in the country where they wrote, as well as reveries of their imagination (341), adding, in a moment of self-reflection, that a similar condition afflicts Christianity. Haven't the Catholics and Protestants, instead of reading the scriptures in Hebrew and Greek, become increasingly attached to interpretations that divide them? The religions and laws, wisdom and the fables of the rest of the world can be traced to ancient India, the traveller insists (7). But that past is all but lost in the current debasement of its people and the disarray of its languages.

The narrative of a barely discernible glorious cultural past recoverable only in Sanskrit is one of the most frequently used tropes of European discourses of India, and one I need not dwell on. But Sonnerat's view of India's languages, however solipsistic, provides an occasion to delve into aspects of vernacular-Sanskrit relations on the subcontinent that confronted the French travellers, one that speaks to how the local in the account emerges in dialogue with the traveller's linguistic ideology. Here his suggestion that this corrupt state is attributable to the absence of cultivation of science (228), alluding most likely to the benefits of standardization, presents an opening.

It helps to recall here that the history of French, a language Antoine Rivarol described as "incorruptible", ${ }^{9}$ has been intimately linked with a strong tradition of purism (Lodge 156), dependent on a codified language legitimized through an elaboration of "bon usage", or "ideology of the standard" (Lodge 178, emphasis in original). "Bon usage", I want to note, paradoxically confirms the existence of "mauvais usage". The omnipresence of patois-defined by the Encyclopédie as "langage corrompu tel qu'il se parle presque dans toutes nos provinces" (qtd. in Lodge 193) ${ }^{10}$ - in seventeenth- and eighteenthcentury France has been widely attested. Sonnerat's attention to Sanskrit seems to play an analogous role (albeit conversely), when, by separating the regional languages as "living" he seems to suggest that Sanskrit is indeed not quite alive among the people. Sheldon Pollock, comparing the situations in south Asia and western Europe in somewhat oppositional ${ }^{11}$ terms, however, notes the role of Sanskrit as a generative force in the life of vernaculars:

\footnotetext{
${ }^{9}$ Rivarol was "particularly motivated by a desire to demonstrate the superiority of French over English" (Lodge 184).

10 Translation: "a corrupt manner of speaking used in more or less all our provinces." The definition adds that "the [French] language is spoken only in the capital."

11 I do not claim that ideologies of purity do not exist in India. On the contrary, Pollock discusses the persistent ideology, among Sanskrit intellectuals in India, as late as the seventeenth century, that viewed vernacular language as a "corrupted dialect" (308). Rather, my intention is to point out that the general attitude toward linguistic plurality and the absence of any institutionally imposed language ideology in eighteenth-century India would be incommensurable with the ideology that underpinned the French accounts.
} 
If the progress of Latin around the beginning of the Common Era entailed the reduction of linguistic diversity across the western Mediterranean world, the progress of Sanskrit entailed the literization of a vast range of vernaculars in southern Asia. Nowhere in the texts of premodern south Asia do we find the least hint of despair at the proliferation of languages. (Pollock 508-509)

[...] the very constitution of peoplehood through kinship, group solidarity, and common culture, especially language-however self-evident a feature of European history-is very hard to demonstrate for any period of South Asian history before modernity and seems just another fallacious universalization of a Western particular. (510)

To understand the construction of the vernacular and the local in the French account, one must also consider the interwoven project of European colonization and the study of language as "intimately linked to the wider colonial emphasis on human hierarchies" (Pennycook 81). The traveller's translation of difference here encompasses an understanding of the vernacular and the local as unsystematic yet static, of language as a pre-given entity that the local puts to use, rather than language as locally produced in the constant restructuring of both the linguistic and the social domain (46).

My point here is not to overemphasize change, or to deny that certain communities identify with certain places over long periods of time. As Selby and Peterson observe, Classical Tamil literature is in fact "explicitly conscious about the close relationships between language, geographical territory, and culture" (4), and "key ideas regarding landscape [...] discerned in the constructions of aesthetic universes in classical Tamil poetics were [...] still recognizable in language and practice in contemporary Tamil discourses about space and identity" (2). But such continuity has emerged, as they point out, in dialogue with heterogeneity-from a mixing of cultural currents (6) that have flowed through the region-rather than in its absence.

\section{Trace of the travellee as translator}

If travel writing has always depended on translation for its construction and dissemination, it has also typically obscured, or pathologized the role of the translator-travellee in that enterprise. While there are numerous references to the local translators or dobachis ${ }^{12}$ (dubash in English) in the French accounts of India from the period under examination, one finds very few mentions of names. In his Voyage dans l'Inde et au Bengale (1801), Frenchman Grandpré ${ }^{13}$ writes about the near-total dependence of European travellers on

\footnotetext{
12 Also known as munshis or pandits.

13 Travelled in the subcontinent in 1789-90.
} 
dobachis - the latter generally conversant in multiple Indian and European languages (Grandpré 19). Functioning as translator, advisor, guide, broker, and moneylender, a dobachi was often the traveller's primary source of contact with Indian society (Neild-Basu 2), "rank[ing] high among the shared experiences of European colonial life in Madras" (Neild-Basu 14). Swiss-French Polier, ${ }^{14}$ famous for his Persian letters titled I'jaz-i-Arsalani (1773-1779) ${ }^{15}$ and a key presence in the network of Europeans that helped advance the English East India Company's imperial project in India in the eighteenth century (Alam and Alavi), employed multiple munshis to write the letters on his behalf (Alam and Alavi 13)..$^{16}$ While generally following a format of Indo-Persian letter-writing style of the period, the letters are also marked by striking differences reflecting "the individual writer's varying appreciation of received diction" (17). The zone of the translator-travellee, one must note, was largely a vernacular one, and their importance to the Europeans lay in "their ability to mediate between the living languages of India and its classical past" (Hatcher 110).

The earliest publication in Europe of the Bhagavata Purana ${ }^{17}$ was the French version titled Bagavadam (1788). Edited and published by traveller and naturalist Foucher d'Obsonville, ${ }^{18}$ it was translated in 1769 by Maridas Pillai (also known as Maridas Poullé),${ }^{19}$ a Tamil Catholic in Pondicherry. As chief interpreter for the French in that comptoir, he played a prominent role as translator/interpreter for travellers ranging from missionary Coeurdoux and philologist Anquetil-Duperron, to naturalist Sonnerat and astronomer Le Gentil (Mohan). Pillai is believed to have based his French translation not on Sanskrit but an abridged Tamil version of the Purana. According d'Obsonville, upon its completion (long before its publication by the Frenchman), the translator clandestinely sold his work to European buyers - both Anquetil-Duperron and Sonnerat (Le Blanc 17) are known to have acquired copies of the manuscript. In his "discours préliminaire" to the 1788 publication, d'Obsonville notes the treachery of the Indian interpreter:

I had absolutely lost sight of this abuse of confidence, but about four years ago, reading a modern book of travels [...]l discovered, from several passages and even from whole pages, that the Indian had sold to the author a copy of this translation, and of several other works purchased at my expense. (viii)

The traveller goes on to frame the translation in terms commonly found in Orientalist discourses of India:

\footnotetext{
14 Lived in India between 1757-1788.

${ }^{15}$ A compilation of his correspondence with the locals of Awadh and Delhi during his stay in those places.

${ }^{16}$ According to Alam \& Alavi, the "variations in style" suggest that the letters were written by "diverse hands" (13).

17 Hindu sacred text, one of the eighteen Puranas-a compendium of traditions, legends and sermons (Das 172).

18 Travelled in India between 1754 and 1769.

19 Pillai is believed to have been commissioned by d'Obsonville to translate the Purana.
} 
The copy that reached Europe in 1769 or 1770 can only be inaccurate, often conveying a meaning that is questionable. This is sufficiently clear from the quotations of the learned who have consulted it ${ }^{20}[\ldots]$ The Indian interpreter, being a Christian, may have misunderstood aspects of the canonical text. $[\ldots]$ It was therefore necessary to restore it to its original simplicity by ridding it of unrecognizable terms and unreliable synonyms. This may have resulted in abrupt transitions and digressions, but the custom of interrupting the narrative to instruct is after all part of the Homeric tradition practiced through antiquity. (x-xi, my translation)

The assumption at work in d'Obsonville's account (as in Sonnerat's) is that the vernacular languages of India are derived from Sanskrit. But the etymology of Sanskrit, meaning "perfected" or "artificial", could be taken to suggest that the vernaculars preceded a purified Sanskrit, the latter's power lying in its "nonintelligibility and unavailability" (Doniger 18-19). A more relevant point to consider here would be the back-and-forth flow between Sanskrit and vernacular knowledges - termed by Doniger as processes of "crossfertilization" (19), in the course of which local gods might get Sanskrit names and "Sanskrit gods take on characteristics of local gods" (19). Around the middle of the second millennium, these processes underwent a significant transformation, when vernaculars like Tamil came to compete with and replace Sanskrit as the language of literature while absorbing the latter's conventions and ideologies (Doniger 19). Examples of this phenomenon could be found in the retellings of the Puranas, which came to incorporate local stories into Sanskrit categories. Pillai's translation, and the vernacular-Sanskrit relation that d'Obsonville and his contemporaries encountered, need to be seen in light of such crisscrossing of influences-mostly deliberate and produced, rather than destined (Pollock 504). Instead of recognizing the Bagavadam as a work of vernacular literature, d'Obsonville and Europeans following him looked for a Sanskrit original which might point to a universal, deistic, monotheistic history of humankind. The attempt to insert Sanskrit into a universal history of the world paradoxically rested on ignoring the mutually constitutive roles of the vernacular and Sanskrit at specific moments in local histories.

D'Obsonville's criticism also had to do with the reach and influence of Pillai's work in Europe. In the preface he berates the Tamil translator-travellee for suggesting that the Puranas may have come after the establishment of Islam in India, an idea that was subsequently adopted by several European scholars. Indeed, the view that the Bhagavata Purana is of a much more recent date than had been previously believed, first put forward by the Orientalist Joseph de Guignes, was based on Pillai's own note to that effect (de Guignes 1772) in the translation. In his criticism, d'Obsonville cites as "incorrect" the French rendering of two words by Pillai: Toulouker as "Turcs" ("Turks") and Miletcher as "Maures" ("Moors"). The translations connect the words to recent invasions, but Toulouker, d'Obsonville argues, refers to the Tartars with whom Indians had had a relation of both trade and war from time immemorial, and Miletcher is a term of Sanskrit origin, signifying anything impure, or ignoble (xxxiv-xxxv). My concern here is not so much

20 My translation draws on the English translation of d'Obsonville's preface published in a review of the Bagavadam in The Monthly Review or Literary Journal (1788, vol. 79, p. 591-593). 
the credibility of the interpretations put forward by Pillai or d'Obsonville, but the implication inherent in the controversy-that, as a religious text, the Bhagavata Purana could at once claim sacred authority based on an organic connection to the Vedic corpus (Gupta and Valpey 2), and testify to its evolution in response to local societal change over time.

The story of the Bagvadam is significant for understanding the role of the translator-travellee in shaping the trajectory and content of knowledge in eighteenthcentury regimes of empire, and embedding vernacular knowledge in the international discursive network(s) where the travel accounts circulated. In 1769, Pillai sent his translation to French Minister and Secretary of State Henri Bertin, who handed it over to Joseph de Guignes. In 1772, sixteen years before its publication by d'Obsonville, de Guignes drew attention to it in Réflexions sur le livre indien intitulé Bhagavadam. PierreSylvain Filliozat credits this moment as crucial to the emergence of Indology on the world stage. De Guignes' notion of universal history relied on translation, and his knowledge of India drew on his correspondences with the polyglot Maridas Pillai ${ }^{21}$ (Mohan), and the latter's translation of the Purana.

\section{Conclusion}

The process of rendering visible the material trace of the travellee-translator, I have argued, must include a view of the (linguistic) ideology at play in the traveller's construction of the other, if we are to appreciate the nature of the transactions involved in the context. My analysis, by way of the vernacular, is meant to dispel any idea of "essential belonging" (Islam 5) on the part of the travellee, the kind Syed Manzurul Islam criticizes in his call for a "non-sedentary" and "non-essentialist" concept of travel that dissolves (Western) travel writing's tendency to draw a clear distinction between the traveller and the travellee (5) based primarily on a "false logic of difference" (3), and a connotation of the travellee's subjectivity as spatially (and culturally) bounded (5):

the relation between the same and the other, more often than not, is grounded in spatial locations, as if space has the natural propensity to entwine individual bodies inhabiting it, shaping them in its very image. (5, emphasis in original)

Attending to the local in language practice is a step toward remapping the homogenizing "view from nowhere" (Schaffer et al. xv) that Islam questions, and foregrounding language and space as "dynamic categories rather than mere context" (Pennycook 80).

It is however worth noting that the travellers' engagement with the vernacular languages of India demonstrates a degree of sensitivity to its multilingualism not typically found in European descriptions of the region. While the importance of local translators to the construction of travel accounts had to do with their ability to mediate between Sanskrit and the vernaculars, the knowledge that resulted from such mediation made its way to larger networks through travellers who ventured to investigate and question received knowledge - whether motivated by curiosity, a need to collect information for themselves,

${ }^{21}$ Pillai's unpublished papers are kept at the Bibliotheque nationale. 
or to pass it on in exchange for a suitable price. But this questioning, much like the discourse of empire of which it was a part, was neither uniform nor coherent. More often than not, in the effort to systematize India's multilingualism and fit it into a specific typology, its specificity eluded them.

In a similar vein, I want to point out that while the translator-travellees are conspicuous by their absence in a majority of French accounts, except as a collective lacking specificity, it is the sporadic mention of names-the dobache Maridas Pillai, the munshi Kishen Sahay, the pandit Ram Chand (Polier) —that makes the accounts at once indispensable and inadequate (Chakravarty 19). ${ }^{22}$ The openings they offer can help foreground language as a local practice where the vernacular emerges as central to tracing the intervention of the translator-travellee in the accounts in question.

\section{Works Cited}

von Adelung, Friedrich. An Historical Sketch of Sanscrit Literature: With Copious Bibliographical Notices of Sanscrit Works and Translations. DA Talboys, 1832.

Alam, Muzaffar, and Seema Alavi. A European Experience of the Mughal Orient: The I'jaz-i Arsalani (Persian Letters, 1773-1779) of Antoine-Louis-Henri Polier. Oxford University Press, 2001.

Anquetil-Duperron, Abraham Hyacinthe. Recherches historiques et geographiques sur I'Inde. Berlin, 1786.

---. "A Brief Account of a Voyage to India Undertaken by M. Anquetil du Perron." The Annual Register, London, 1787.

"Bagavadam, ou Doctrine Divine." The Monthly Review; or, Literary Journal, vol. 79, July 1788, pp. 591-593.

Banerjee, Sanjukta. "Unfixing Multilingualism: India Translated in French Travel Accounts." A Multilingual Nation: Translation and Language Dynamic in India, edited by Rita Kothari, Oxford University Press, 2018, pp. 97-115.

Bassnett, Susan. Comparative Literature: A Critical Introduction. Blackwell, 1993.

---. "Travel Writing and Gender." The Cambridge Companion to Travel Writing. Cambridge University Press, 2002, pp. 225-41

Bracewell, Wendy. "The Travellee's Eye: Reading European Travel Writing, 1750-1850." New Directions in Travel Writing Studies, edited by Julia Kuehn and Paul Smethurst, Palgrave Macmillan, 2015, pp. 215-227.

Calvet, Louis Jean. Language Wars and Linguistic Politics. Translated by Michel Petheram, Oxford University Press on Demand, 1998.

Chakrabarty, Dipesh. Provincializing Europe: Postcolonial Thought and Historical Difference. Princeton University Press, 2009.

"coss | cos, n.2." OED Online, Oxford University Press, July 2018, www.oed.com/view/Entry/42286. Accessed 5 November 2018.

22 Durba Ghosh's discussion of the partial absence of women's voices in colonial archives has informed my point. 
Das, Sisir K. A History of Indian Literature:1800-1910 Western Impact: Indian Response. Sahitya Akademi, 1991.

Dasgupta, Probal. "Trafficking in Words: Languages, Missionaries and Translators." In Translation: Reflections, Refractions, Transformations, edited by Paul St-Pierre and P.C. Kar, John Benjamins Pub., 2007, pp 57-72.

Deleury, Guy. Les Indes florissantes: Anthologie des voyageurs français, 1750-1820. R. Laffont, 1991.

Diderot, Denis, and Jean Le Rond d'Alembert. Encyclopédie Ou Dictionnaire Raisonné Des Sciences, Des Arts et Des Métiers. Paris, 1765.

Doniger, Wendy. "An Alternative Historiography for Hinduism." The Journal of Hindu Studies, no. 2, 2009, pp. 17-26.

Ghosh, Durba. "Decoding the Nameless: Gender, Subjectivity, and Historical Methodologies in Reading the Archives of Colonial India." New Imperial History: Culture, Identity, and Modernity in Britain and the Empire, 1660-1840, edited by Kathleen Wilson, Cambridge University Press, 2004, pp. 297-316.

de Grandpré, Louis. Voyage dans I'Inde et au Bengale, fait dans les années 1789 et 1790, vol. 1, Paris, 1801.

de Guignes, Joseph. "Réflexions sur un livre Indien intitulé Bagavadam." Histoires de l'Académie Royale des Inscriptions et Belles Lettres, vol. 38, 1772, pp. 312-336.

Gupta, Ravi M, and Kenneth R. Valpey. The Bhāgavata Purāna: Sacred Text and Living Tradition. Columbia University Press, 2013.

Islam, Syed Manzurul. The Ethics of Travel: From Marco Polo to Kafka. Manchester University Press, 1996.

Kaviraj, Sudipta. "Writing, Speaking, Being: Language and the Historical Formation of Identities in India." The Imaginary Institution of India: Politics and Ideas. Columbia University Press, 2010, pp. 127-166.

Le Blanc, Claudine. 2009. "Les premiers passeurs de Bhâgavata Purâna." Passeurs d'idées religieuses entre l'Inde et l'Europe, edited by Pflieger-Maillard, Christine, and Ysé Tardan-Masquelier, Presses universitaires de Strasbourg, 2009, pp. 1536.

Lefebvre, Henri. The Production of Space. Translated by Donald Nicholson-Smith, Blackwell, 1984.

Lodge, R. Anthony. French: From Dialect to Standard. Routledge, 1993.

Makoni, Sinfree, and Alastair Pennycook. Disinventing and Reconstituting Languages. Multilingual Matters, 2007.

Massey, Doreen. "Politics and Space/time." New Left Review. No 196, 1992, pp. 65-84.

Mohan, Jyoti. Claiming India: French Scholars and the Preoccupation with India in the Nineteenth Century. SAGE Publishing India, 2017.

Neild-Basu, Susan. "The Dubashes of Madras." Modern Asian Studies, no. 18, 1984, pp.1-31.

Pennycook, Alastair. Language as a Local Practice. Routledge, 2010.

Pollock, Sheldon. The Language of the Gods in the World of Men: Sanskrit, Culture, and Power in Premodern India. University of California Press, 2006. 
Poullé, Maridas, and Foucher d'Obsonville. Bagavadam, ou, doctrine divine: Ouvrage Indien, canonique: sur l'être suprême, les dieux, les géans,les hommes, les diverses parties de l'Univers, etc. Paris, 1788.

Poullé, Maridas, and Henry Hosten. Le Bhâgavata. D'après un texte Sen Tamoul. Nouvelle traduction de Maridas Poullé de Pondichéry (1793-1795). Pondichéry: Société de l'histoire de de l'Inde française, 1921.

Pratt, Mary Louise. Imperial Eyes: Travel Writing and Transculturation. Routledge, 2008.

Raj, Kapil. "Mapping Knowledge: Go-Betweens in Calcutta, 1770-1820." The Brokered World: Go-Betweens and Global Intelligence: 1770-1820, edited by Simon Schaffer et al., Science History Publications 2009, pp. 105-50.

de Rivarol, Antoine. De l'Universalité de la langue française; discours qui a remporté le prix à l'Académie de Berlin, edited by $\mathrm{H}$. Juin, Paris, 1784.

Rocher, Ludo. The Puranas. Otto Harrassowitz, 1986.

Romaine, Suzanne. Language in Society: An Introduction to Sociolinguistics. Oxford University Press, 2000.

Said, Edward. Orientalism. Vintage Books, 2003.

---. Culture and Imperialism. Vintage Books, 1993.

Selby, Martha Ann., and Indira Viswanathan Peterson. Tamil Geographies: Cultural Constructions of Space and Place in South India. SUNY Press, 2008.

Singh, Kumar Suresh, and S. Manoharan. Languages and Scripts. Oxford University Press, 1993.

Smith, Barbara Herrnstein. Contingencies of Value: Alternative Perspectives for Critical Theory. Harvard University Press, 1991.

Soja, Edward W. Postmodern Geographies: The Reassertion of Space in Critical Social Theory. Verso, 1989.

---. Thirdspace: Journeys to Los Angeles and Other Real-and-Imagined Places. Blackwell, 1996.

Sonnerat, Pierre and C S. Sonnini. Voyage aux Indes orientales et à la Chine fait Par ordre de Louis XVI depuis 1774 jusqu'en 1781, vol 1, Paris, 1806.

Subrahmanyam, Sanjay. "Between a Rock and a Hard Place: Some Afterthoughts." The Brokered World: Go-betweens and Global Intelligence, 1770-1820, edited by Simon Schaffer et al., Science History Publications, 2009., pp. 429-440. 